\title{
Wetland Plants' Chemical Ecology for Iron of A Ramsar Site in An Indo-Burma Hotspot: In-Situ Bioaccumulation and Phytoremediation Implications
}

\author{
Prabhat Kumar Rai† and M. Muni Singh \\ Department of Environmental Science, Mizoram University, Aizawl, Mizoram, India \\ $†$ Corresponding author: Prabhat Kumar Rai; mzut127@mzu.edu.in
}

Nat. Env. \& Poll. Tech.

Website: www.neptjournal.com

Received: 04-02-2020

Revised: 17-02-2020

Accepted: 05-03-2020

\section{Key Words:}

Invasive alien plants

Ramsar site

Phytoremediation

Bio-accumulation

Biodiversity

\begin{abstract}
Biogeochemistry of iron in wetlands is inextricably linked with chemical ecology of aquatic biota impacting the ecology of wetland plants and human health. Therefore, its bio-accumulation in plants is of extreme eco-technological relevance in quest of potential phytoremediation tools. To this end, the Fe concentrations in water and four invasive alien macrophytes (Eichhornia crassipes, Lemna minor, Pistia stratiotes and Salvinia cucullata) of Loktak lake (a Ramsar Site) were measured. Further, the outcome of the present research can assess the efficiency of these plants in Fe-phytoremediation. Concomitantly, to get an explicit Fe-macrophyte's chemical ecology scenario of Loktak lake, physicochemical parameters as well as biodiversity attributes were also investigated. Results revealed that among the four plant species, Pistia stratiotes accumulated the highest amount of Fe concentration and thus act as the best bio-accumulator of Fe. Further, the extent of Fe bio-accumulation was as Pistia stratiotes $>$ Lemna minor>Eichhornia crassipes $>$ Salvinia cucullata. The study revealed the importance of the selected invasive wetland plants as the potential bio-agents of Fe accumulation.
\end{abstract}

\section{INTRODUCTION}

Global wetland systems offer immense ecosystem services to humanity with their unique ecological/environmental features and biodiversity of floating and/or submerged macrophytes (Prasad et al. 2002, Bassi et al. 2014, Rai et al. 2018). However, recent decades witnessed a paradigm shift in wetland's health in view of the abrupt increase in environmental contaminants. In this respect, it has been well known that natural wetlands demonstrate a majestic chemical ecology in remediating the metallic contaminants. Thus, elucidating the complex chemical and ecological interactions existing in the wetland systems can pave the way for phytoremediation, hence ecological restoration (Valderrama et al. 2013, Evangelou et al. 2013, Singh \& Rai 2016, Al-Baldawi et al. 2017, Rai \& Kim 2019, Rai et al. 2020).

Several macrophytes of Indian Ramsar wetlands, e.g. Phragmites australis (of Hokersar wetlands in Kashmir Himalaya) have been identified for their phytoremediation potential of heavy metals (Chatterjee et al. 2011, Ahmad et al. 2014, Khatun 2016). Moreover, in this context elucidation of mechanisms leading to integrated restoration/eco-management of Kolleru lake (a Ramsar wetland in Andhra Pradesh, India) abridged the chemistry with ecological restoration (Sharma \& Sujatha 2016). Thus, the heavy metal pollution of global wetland systems and their phytoremediation attained considerable research attention (Feng et al. 2017, Rai 2018; Rai 2019, Rai et al. 2019).
The excess use of agrochemicals (including fertilizer and plant nutrients) contaminate soil, water and food crops/vegetables with heavy metals (Rai 2008, Alhashemi et al. 2011, Fatima et al. 2014, Rai et al. 2020). Also, the bioavailability of heavy metals is remarkably influenced by the geochemical factors in global wetlands (Fairbrother 2007). Moreover, the sediments of the wetland effectively sequester hydrophobic chemical pollutants which are readily available from various pollutant discharges (Rai et al. 2018).

Natural wetlands are the important sink for environmental pollutants in view of their complex physico-chemical and biogeochemical mechanisms operating inside wetlands (Jiao et al. 2014, Xin et al. 2014, Zhang et al. 2016). It has been well known that aquatic/wetland plants absorb emerging contaminants and nutrients from the water/sediments of natural wetlands in view of being interfaces with them (Xue et al. 2010, Rai et al. 2019). For a low level of environmental contamination, the aquatic plants (mostly invasive aliens) also act as ecological indicators (Pratas et al. 2012, Borisova et al. 2014, Rai \& Singh 2020). Therefore, in environmental biotechnology, the screening of macrophytes for phytoremediation of metallic contaminants has also received tremendous attention (Sood et al. 2012, Borisova et al. 2014, Rai et al. 2019).

Phyto-technological investigations in global biodiversity hotspots especially from North East Indian sites are rarely investigated for pollution ecology of Ramsar wetland plants. 
The sewage is eventually drained into the Ramsar wetland (Loktak lake) may also result in eutrophication as well as contamination of the lake with heavy metals of extreme human health concerns (Meitei et al. 2016, Rai 2018a). In Indian prospect, 26 Ramsar wetlands of ecological importance are listed (out of the current total of 37 wetlands under the Ramsar convention), facing the environmental perturbations in one form or other (Tombi \& Shyamananda 1994; Ramsar secretariat 2013, Bassi et al. 2014, Rai 2018). The scientific investigations of Ramsar sites tend to provide their current global status in order to fill up the knowledge gap pertaining to their metals biogeochemistry and aquatic plants ecology.

Iron $(\mathrm{Fe})$ plays a crucial role in various bio-systems (plants as well as animals) due to its involvement in biochemical pathways, metabolic machinery, respiratory functions (being an integral component of haemoglobin) and in DNA synthesis (Ghaly et al. 2008, Rai et al. 2018a). Nevertheless, $\mathrm{Fe}$ is also toxic in higher concentration ranges to living entities of the wetland ecosystem and propensity to cause human health risks in case of metals transfer through food chain. In the present study, considering the all the stress caused by the $\mathrm{Fe}$ (as other metallic contaminants were negligible), the authors aim to analyse and determine the amount of $\mathrm{Fe}$ accumulation in aquatic bodies as well as selected aquatic plants such as Eichhornia crassipes, Lemna minor, Pistia stratiotes and Salvinia cucullata of Loktak lake to know the

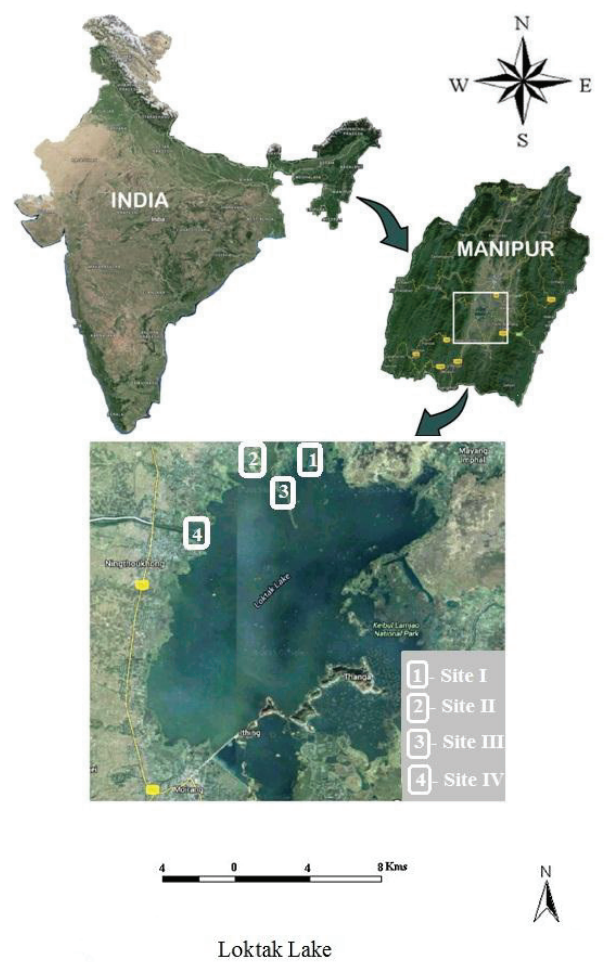

efficiency of their bio-accumulation/phytoremediation. Physicochemical parameters not only affect the concentrations of metallic contaminants but also creating unique relationships among and within the biotic and abiotic components of the ecosystem (APHA 2005, Rai 2010). Henceforth, chemical/ physicochemical parameters and ecological attributes (phytosociology/biodiversity) were also studied to have an integrated chemical as well as the ecological approach. It is worth mentioning that these selected wetland plants are invasive aliens, perturbing the aquatic biodiversity. Nevertheless, their controlled utilization as contaminant's hyperaccumulators can assist their sustainable management, concomitantly, decontaminating the organic/inorganic pollutants from the environment (Rai \& Kim 2019).

\section{MATERIALS AND METHODS}

\section{Study Area}

Loktak lake (Ramsar site; Latitude of $24^{\circ} 25^{\prime}-24^{\circ} 42^{\prime} \mathrm{N}$ and Longitude of $93^{\circ} 46^{\prime}-93^{\circ} 55^{\prime} \mathrm{E}$ ) lies in the middle of the state Manipur situated in the north-eastern part of India.

\section{Sampling Sites}

A total of four sampling sites were selected for analysis which is explicitly described in Fig. 1. The basis of the site selection was attributed to the source of pollution and other anthropo-

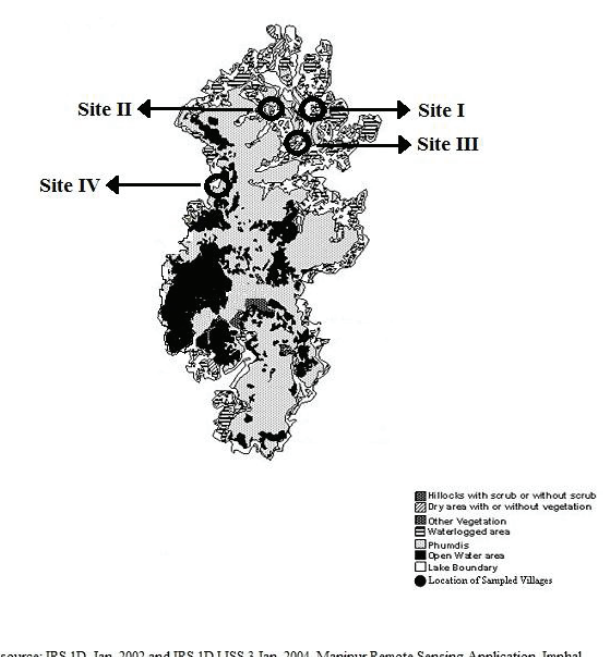

Fig. 1: Study area and location of study in Manipur, North East India (an Indo-Burma hotspot region). 
genic disturbances in the vicinity of this Ramsar lake. The Sites are as follows. Site I (Loktak Nambul vicinity); Site II (Loktak Nambol vicinity, Nambol river carries waste of the Bishenpur municipal area); Site III (Loktak Yangoi vicinity, located at the confluence of Yangoi river); Site IV (Loktak proper, near National Hydro Power Corporation Limited of Loktak lake).

Water samples in triplicate (in $2 \mathrm{~L}$ polythene bottles) were collected in the morning between 6:30 to 9:30 a.m. in rainy, winter and summer seasons from August 2013 to July 2015, and immediately brought to the laboratory for analysis. In addition to physicochemical parameters, we confined our quest on $\mathrm{Fe}$ as it was the only metal recorded above the permissible limit in natural water and wetland plants (Singh \& Rai 2016). Other hazardous heavy metals like $\mathrm{Hg}, \mathrm{Cr}, \mathrm{Pb}$, $\mathrm{Hg}$, As (a metalloid) and $\mathrm{Zn}$ were recorded in negligible/ trace concentrations in water and wetland plants. Henceforth, this fact prompted us to carry out a detailed chemical and biological study in relation to screening the different wetland plants for their possible role in bio-accumulation and phytoremediation of iron $(\mathrm{Fe})$.

\section{Phytosociological Analysis}

Vegetation analysis was carried out by following the standard methods as outlined in Misra (1968), Kershaw (1973) and Mueller-Dombois \& Ellenberg (1974). Harvest methods were adopted for phytosociological analysis on the macrophytes and quadrats $(1 \mathrm{~m} \times 1 \mathrm{~m})$ were used. Macrophytic diversity has been calculated using the following indices.

Iron Analysis of Water and Wetland Plants

The water samples were filtered through $45 \mu \mathrm{m}$ syringe filter and metals were determined by Microwave Induced Plasma Atomic Emission Spectrophotometer (MP-AES: Agilent-4100) available in Central Instrumentation Laboratory (CIL), Mizoram University, India. The fresh macrophytes samples were weighed and kept in the oven for drying and temperature was maintained at $802^{\circ} \mathrm{C}$ for 24 hours. The dried plant samples were again weighed and crushed it into powder. The powdered plant samples were then digested using the di-acid method as mentioned elsewhere (APHA 2005).

\section{RESULTS AND DISCUSSION}

\section{Iron Accumulation in Water}

The Fe concentrations of water at different sites during different seasons were measured and presented in Table 1. As mentioned before, the chemical, as well as physical (physico-chemical/water quality) parameters, play a vital role in bio-availability of heavy metals in water and wetland plants (Rai 2010), therefore, it was duly monitored in conjunction with ecological studies. Fig. 2(a-f) explicitly describe the seasonal variations in different water quality parameters recorded during the study period.

Pertaining to the metal concentrations (analysed in the year 2013-15), the highest value of Fe concentration was measured as $0.17 \mathrm{mg} . \mathrm{L}^{-1}$ at Site IV during winter season of 2014 followed by $0.15 \mathrm{mg} . \mathrm{L}^{-1}$ at Site II and Site IV during the winter season and $0.13 \mathrm{mg} . \mathrm{L}^{-1}$ at Site II during the winter season of the same year 2014. The lowest value of $0.01 \mathrm{mg} . \mathrm{L}^{-}$ ${ }^{1}$ was observed at Site I during the rainy season and summer season of 2014, as demonstrated clearly in Fig. 3. Seasonal variations revealed that $\mathrm{Fe}$ accumulation in lake water is higher during the winter season. However, comparatively low values were measured during the rainy season (attributed to dilution) and summer season for all the sampling periods.

\section{Fe Accumulation in Plants}

The four plant species samples were collected in triplicate from all the four sites in winter season. The trends of $\mathrm{Fe}$ concentrations are shown in Figs. 4-7. Results revealed that among the plants, the highest Fe concentration was measured $28.29 \mathrm{mg} . \mathrm{kg}^{-1}$ in Pistia stratiotes at Site II followed by 13.01 mg.kg ${ }^{-1}$ and $12.68 \mathrm{mg} . \mathrm{kg}^{-1}$ in Pistia stratiotes at Site I and Site III, $12.74 \mathrm{mg} . \mathrm{kg}^{-1}$ and $12.52 \mathrm{mg} . \mathrm{kg}^{-1}$ in Lemna minor at Site I and Site II. The lowest value of $1.68 \mathrm{mg} \cdot \mathrm{kg}^{-1}$ was measured in Salvinia cucullata at Site I (Table 2). The highest value $28.29 \mathrm{mg} \cdot \mathrm{kg}^{-1}$ is higher than the permissible limit set by World Health Organisation (WHO), i.e. $20 \mathrm{mg} \cdot \mathrm{kg}^{-1}$. Salvinia cucullata has the lowest $\mathrm{Fe}$ as compared to the other plant species, i.e. Eichhornia crassipes, Lemna minor and Pistia stratiotes.

Table 1: Fe concentrations (mg.L $\mathrm{L}^{-1}$ ) of water from different study sites (average of three replicates).

\begin{tabular}{|lllllll|}
\hline Study & \multicolumn{3}{c|}{ 2013-2014 } & \multicolumn{2}{c|}{ 2014-2015 } \\
\cline { 2 - 6 } Sites & Rainy & Winter & Summer & Rainy & Winter & Summer \\
Site I & 0.02 & 0.07 & 0.03 & 0.01 & 0.08 & 0.01 \\
Site II & 0.08 & 0.13 & 0.1 & 0.07 & 0.15 & 0.09 \\
Site III & 0.04 & 0.1 & 0.06 & 0.06 & 0.12 & 0.15 \\
Site IV & 0.08 & 0.17 & 0.06 & 0.05 & 0.07 \\
\hline
\end{tabular}




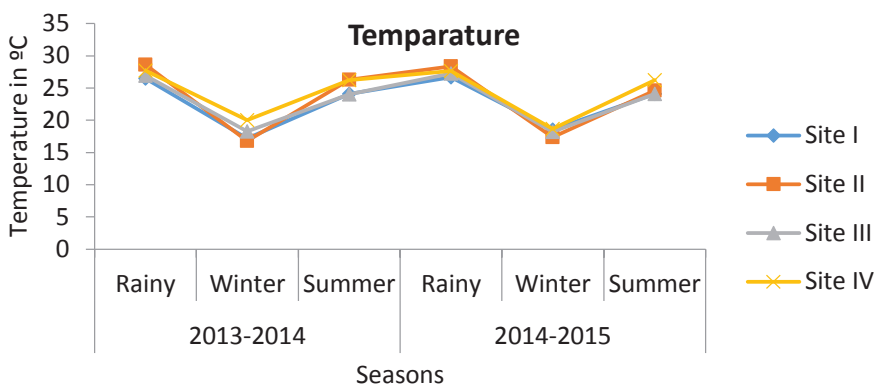

Fig. 2a

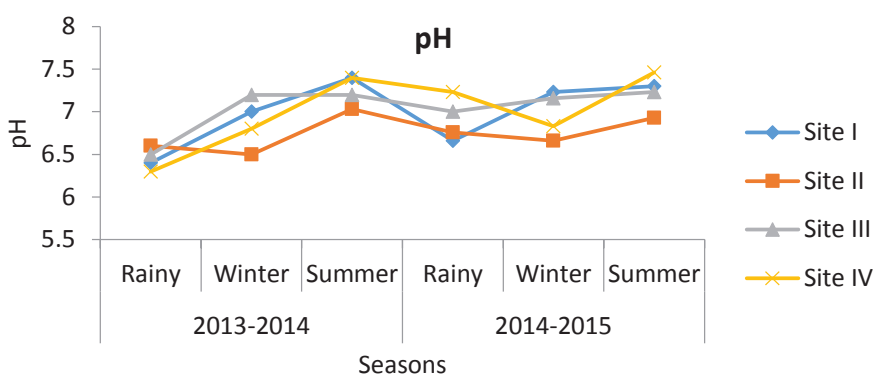

Fig. $2 b$

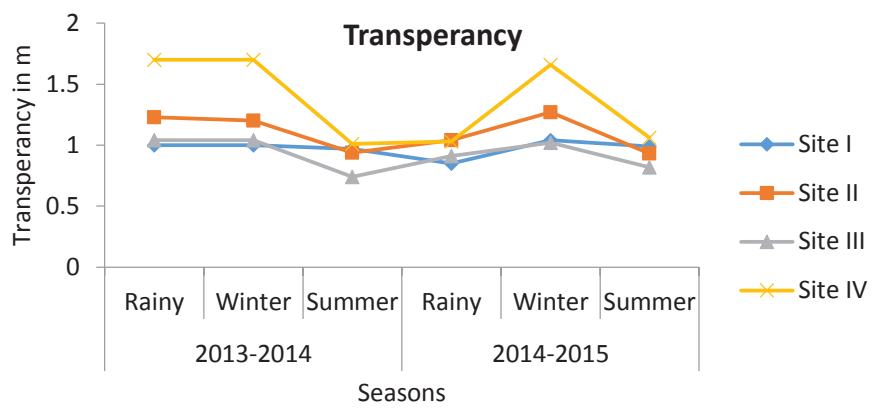

Fig.2c

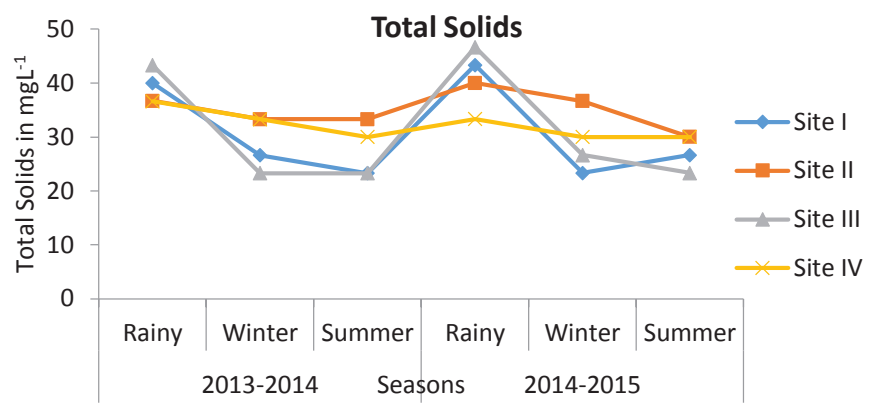

Fig. 2d 


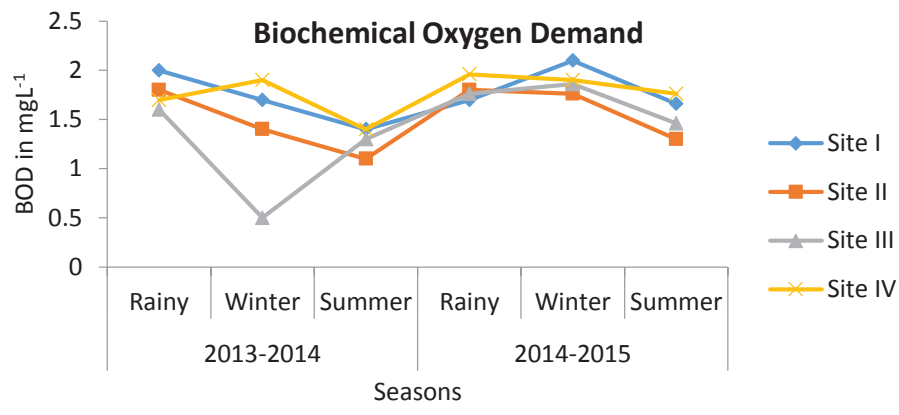

Fig. 2e

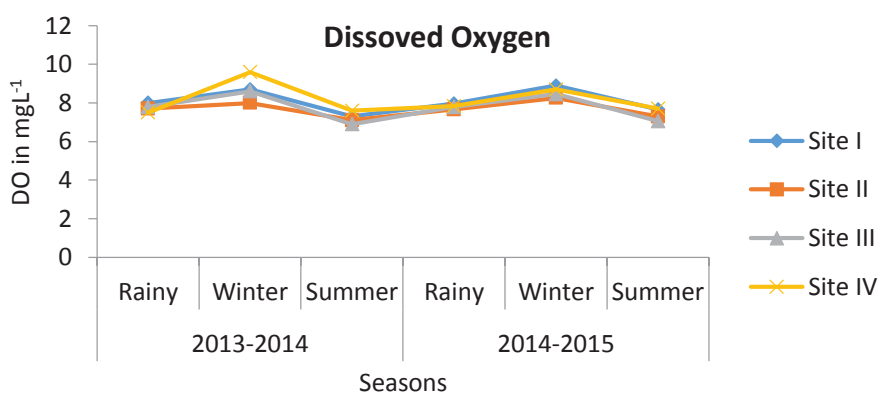

Fig. $2 f$

Fig. 2a-f: Seasonal variations in chemical/physicochemical/water quality parameters at all the four sites of the study area, i.e. Ramsar wetland (Loktak lake, N.E. India of biodiversity hot spot).

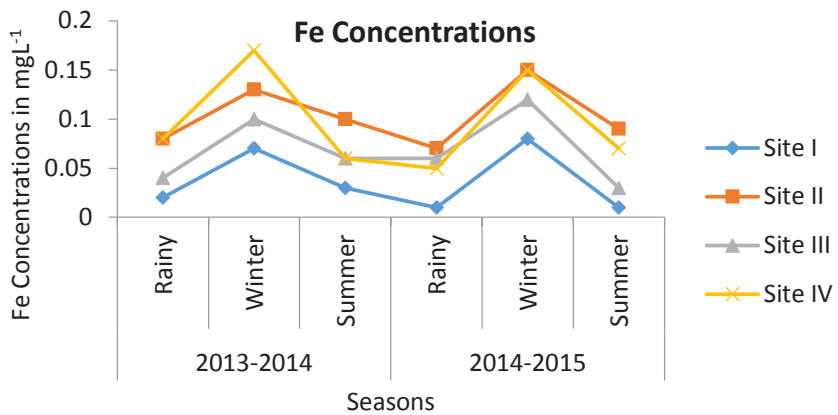

Fig. 3: Seasonal variations of Fe concentrations (in $\mathrm{mg} . \mathrm{L}^{-1}$ ) of water from different study sites.

Table 2: Fe concentrations (in mg. $\mathrm{kg}^{-1}$ ) of plants from different study sites.

\begin{tabular}{|lllll|}
\hline Name of the plants/macrophytes & Site I & Site II & Site III & Site IV \\
\hline Eichhornia crassipes & 0.72 & 9.77 & 9.07 & 9.53 \\
Lemna minor & 12.52 & 12.74 & 9.92 & 12.68 \\
Pistia stratiotes & 13.01 & 28.29 & 3.09 \\
Salvinia cucullata & 1.68 & 3.14 & 2.72 \\
\hline
\end{tabular}




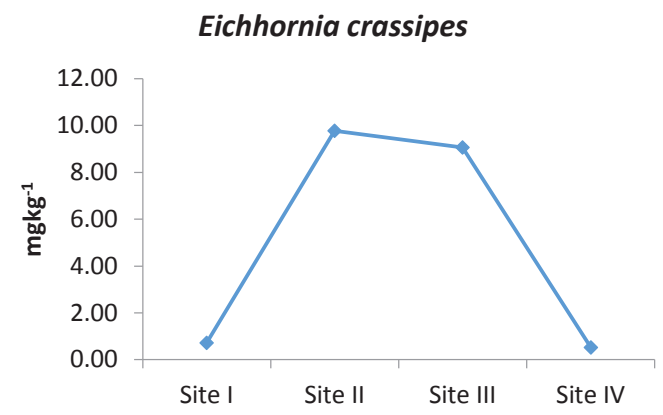

Fig. 4: Fe concentrations (in mg.kg ${ }^{-1}$ ) in Eichhornia crassipes of different study sites.

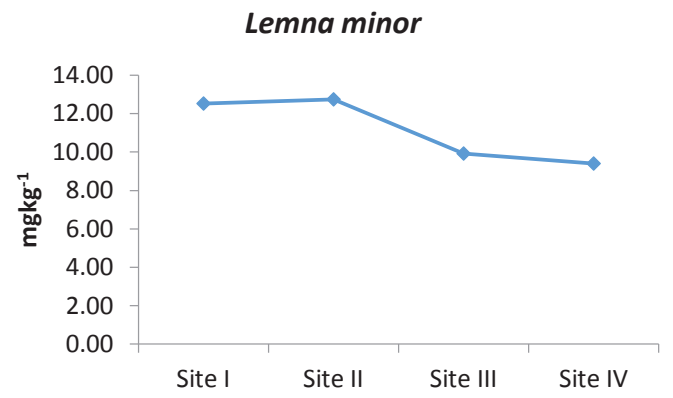

Fig. 5: Fe concentrations (in mg. $\mathrm{kg}^{-1}$ ) in Lemna minor of different study sites.

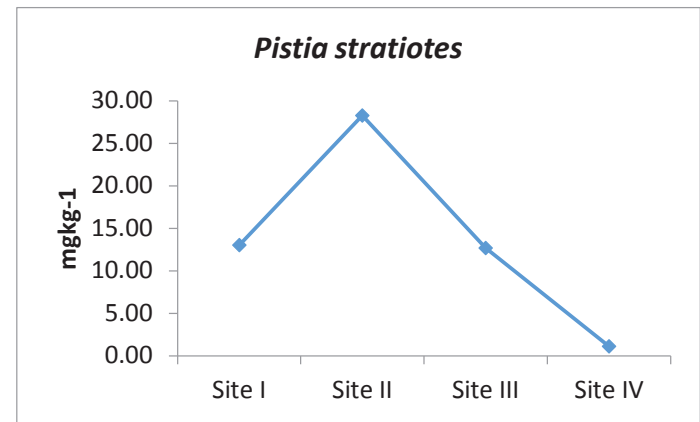

Fig. 6: F e concentrations (in $\mathrm{mgkg}^{-1}$ ) in Pistia stratiotes of different study sites.

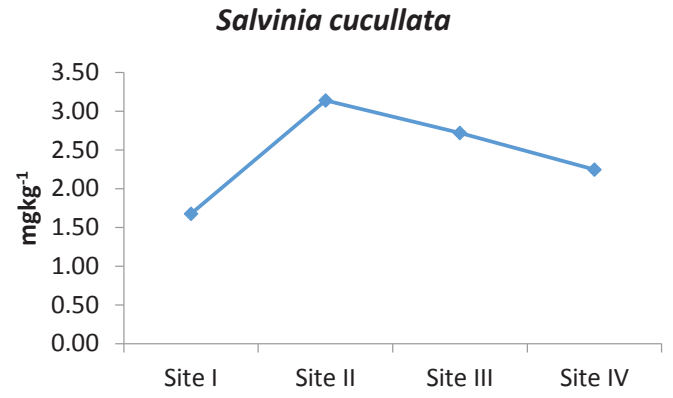

Fig.7: Fe concentrations (in $\mathrm{mgkg}^{-1}$ ) in Salvinia cucullata of different study sites. 
Table 3: Ecological/phytosociological attributes of wetland plants/macrophyte species in Ramsar (Loktak) lake.

\begin{tabular}{|lllll|}
\hline Parameter & Site I & Site II & Site III & Site IV \\
\hline Number of Families & 8 & 11 & 9 & 15 \\
Number of Genera & 8 & 12 & 11 & 20 \\
Number of Species & 10 & 13 & 12 & 21 \\
Simpson Index of Dominance & 0.37 & 0.27 & 0.42 & 0.12 \\
Shannon-Weiner Diversity Index & 1.31 & 1.68 & 1.37 & 2.37 \\
\hline
\end{tabular}

Table 4: Sorenson's Similarity Index between different sites of Ramsar (Loktak) lake.

\begin{tabular}{|lllll|}
\hline & Site I & Site II & Site III & Site IV \\
\hline Site I & & & & \\
Site II & 0.87 & & \\
Site III & 0.73 & 0.72 & 0.61 & \\
Site IV & 0.65 & 0.71 & \\
\hline
\end{tabular}

Table 5: Family-wise distribution of wetland plants/macrophyte species in Ramsar (Loktak) lake.

\begin{tabular}{|llllll|}
\hline S1. No. & Family & Site I & Site II & Site III & Site IV \\
\hline 1 & Amaranthaceae & 1 & 1 & 1 & 1 \\
2 & Apiaceae & - & - & - & 1 \\
3 & Araceae & 1 & 1 & 1 & 1 \\
4 & Asteraceae & - & 1 & - & - \\
5 & Azollaceae & 1 & 1 & 1 & 1 \\
6 & Ceratophyllaceae & 1 & 1 & - & 1 \\
7 & Convolvulaceae & - & - & 1 & 1 \\
8 & Hydrocharitaceae & 1 & 1 & - & 2 \\
9 & Lemnaceae & 2 & 2 & 2 & 1 \\
10 & Menyanthaceae & - & 1 & - & 2 \\
11 & Nymphaeaceae & - & - & - & 3 \\
12 & Poaceae & - & 1 & 1 & - \\
13 & Polygonaceae & - & - & 2 & 1 \\
14 & Pontederiaceae & 1 & 1 & 1 & 2 \\
15 & Potamogetonaceae & - & - & - & 1 \\
16 & Salviniaceae & 2 & 2 & - & 2 \\
17 & Trapaceae & - & - & & 2 \\
\hline
\end{tabular}

(-) Absent

From the present studies, it has been noted that Pistia stratiotes accumulate high amount of Fe concentration from the lake. The recorded trend of Fe bio-accumulation was as Pistia stratiotes $>$ Lemna minor $>$ Eichhornia crassipes $>$ Salvinia cucullata. In this context, high concentrations of $\mathrm{Fe}$ in water samples might be attributed to the pollution caused by draining rivers and the domestic/urban waste from human settlements.
From the phytosociological/ecological studies of the different sites of Loktak lake, altogether a total of 24 wetland plant species belonging to 23 genera and 17 families were recorded. Of this, 10 species belonging to 8 genera and 8 families, 13 species belonging to 12 genera and 11 families, 12 species belonging to 11 genera and 9 families and 21 species belonging to 20 genera and 15 families were reported from Site I, Site II, Site III and Site IV respectively (Table 3). To 
this end, among 24 plants recorded, Alternanthera philoxeroides Griseb., Azolla pinnata Lam., Eichhornia crassipes Linn., Lemna minor Linn., Pistia stratiotes Linn.,Salvinia cucullata Roxb., Salvinia natans Hoffm., and Spirodela polyrhiza (Linn) Schleid. were the plants with higher density at all the sites. Biodiversity/phytosociological attributes related data of macrophyte/wetland plant species is calculated in the study (Table 4). Shannon-Weiner diversity index for macrophyte species was highest at the Site IV i.e. 2.37 and lowest in the Site I i.e. 1.31. However, a reverse trend in the results was observed in the case of the Simpson index of dominance. The Simpson index of dominance was maximum at Site III i.e. 0.42 and minimum at Site IV i.e. 0.12. Table 5 shows the present dominance and diversity of wetland plants in this Ramsar lake. As the Simpson's index of dominance values decreases, Shannon-Weiner diversity increased which is quite appropriate in ecological perspective.

Pertaining to Fe bio-accumulation/remediation, many studies have documented the Fe accumulation and ability of these wetland plants from wastewaters which are rich in nutrients (Singh \& Rai 2016). Ghaly et al. (2008) studied the accumulation of Fe by different aquatic plants including broad leaved cattail, soft stem bulrush, soft rush and wool grass plants from the contaminated water.

P. stratiotes has also been extensively used for removal of heavy metals other than Fe (Rai 2018a). The removal of heavy metals by $P$. stratiotes in the laboratory was tested (Miretzky 2010). Lu et al. (2011) reported that Pistia is a hyper-accumulator of $\mathrm{Cu}, \mathrm{Fe}$, and $\mathrm{Pb}$. Also, Pistia stratiotes was found to be the best phytoremediator for $\mathrm{Cu}$ and $\mathrm{Pb}$ in removing $66.5 \%$ and $70.7 \%$ of these metals (Lone et al. 2008). To this end, remarkable advances in instrumentation assisted metals analysis in wetland plants (Feng et al. 2017). However, to our best of knowledge, the present study is the first report on Pistia stratiotes as a better tool as an ecological indicator of Fe.

\section{CONCLUSION}

From the findings of the present study, it can be concluded that the water of the Loktak lake is contaminated with Fe to a reasonable extent and may further exacerbate in due course of time. However, the other heavy metals were well below the permissible limit in water sediments and biota. To this end, wetland plants can be a remarkable tool and this study revealed differential extent of Fe bio-accumulation among macrophytes (Pistia stratiotes $>$ Lemna minor $>$ Eichhornia crassipes $>$ Salvinia cucullata). The present study can possibly be the first report on Pistia stratiotes as a better tool in relation to bio-accumulation of Fe. Henceforth, the wetland plants play an important role in indicating the Fe concentration of the water as well as the extent of accumulation in the plants itself. Interestingly, the studied macrophytes are actually invasive aliens, perturbing the aquatic ecology/biochemistry. Nevertheless, their controlled utilization as contaminant's hyperaccumulators can assist in their sustainable management, concomitantly, decontaminating the organic/ inorganic pollutants from the total environment.

\section{ACKNOWLEDGEMENT}

The author is thankful to Department of Biotechnology (BT/PR24917/NER/95/907/2017), New Delhi, India and Department of Science and Technology (WTI Nexus Project-TPN/33209-No. DST/TMD-EWO/WTI/2K19/ EWFH/2019/190) for financial assistance. Thanks are due to University Grants Commission of India and Dr. M. Muni Singh.

\section{REFERENCES}

Ahmad, S.S., Reshi, Z.A., Shah, M.A., Rashid, I., Ara, R. and Andrabi, S.M.A. 2014. Phytoremediation potential of Phragmites australis. Int. J. Phytoremediation, 16(7-12): 1183-1191.

Al-Baldawi, I.A., Abdullah, S.R.S., Anuar, N. and Mushrifah, I. 2017. Bioaugmentation for the enhancement of hydrocarbon phytoremediation by rhizobacteria consortium in pilot horizontal subsurface flow constructed wetlands. Inter. J. Environ. Sci. Technol., 14: 75-84.

Alhashemi, A.H., Karbassi, A.R., Kiabi, B.H., Monavari, S.M. and Nabavi, M.B. 2011. Accumulation and bioaccessibility of trace element in wetland sediments. African J. Biotechnol., 10: 1625-1638.

APHA, 2005. Standard methods for the examination of water and wastewater. American Water Works Association, Water Environment Federation, American Public Health Association. Washington, DC: pp.144.

Bassi, N., Kumar, M.D., Sharma, A. and Pardha-Saradhi, P. 2014. Status of wetlands in India: A review of extend, ecosystem benefits, threats and management strategies. J. Hydrol. Regional Studies, 2: 1-19.

Borisova, G., Chukina, N., Maleva, M. and Prasad, M.N.V. 2014. Certophyllum demersum L. and Potamogeton alpines Balb. From Iset' River, Ural Region, Russia differ in adaptive strategies to heavy metals exposure-A comparative study. Inter. J. Phytorem., 16: 621-633.

Chatterjee, S., Chetia, M., Singh, L., Chattopadhyay, L., Datta, S. and Mukhopadhyay, S.K. 2011. A study on the phytoaccumulation of waste elements in wetland plants of a Ramsar Site in India. Environ.Monit. Assess., 178: 361-371.

Evangelou, M.W.H., Ebel, M. and Schaeffer, A. 2007. Chelate assisted phytoextraction of heavy metals from soil. Effect, mechanism, toxicity, and fate of chelating agents. Chemosphere, 68: 989-1003.

Fairbrother, A., Wenstel, R., Sappington, S. and Wood, W. 2007. Framework for metals risk assessment. Ecotoxico. Environmen. Safety, 68: 145-227.

Fatima, M., Usmani, N., Hossain, M.M., Siddiqui, M.F., Zafeer, M.F., Firdaus, F. and Ahmad, S. 2014. Assessment of gentoxic induction and deterioration of fish quality in commercial species due to heavy-metal exposure in an urban reservoir. Archive Environ. Contamination Toxicol., 67: 203-213.

Feng, H., Qian, Y., Cochran, J.K., Zhu, Q., Hu, W., Yan, H., Li, L., Huang, 
X., Chu, Y.S., Liu, H., Yoo, S. and Liu, C. 2017. Nanoscale measurement of trace element distributions in Spartina alterniflora root tissue during dormancy. Sci. Reports, 7: 40420.

Ghaly, A.E., Snow, A. and Kamal, M. 2008. Kinetics of Iron uptake by wetland plants. American J. Biochem. Biotechnol., 4: 279-287.

Jiao, W., Ouyang, W., Hao, F.H., Wang, F.L. and Liu, B. 2014. Long-term cultivation impact on the heavy metal behavior in a reclaimed wetland, Northeast China. Environmental Pollution, 147: 311-323.

Kershaw, K.A. 1973. Quantitative and Dynamic plant Ecology. Edward Arnold LTD., London.

Khatun, A. 2016. Evaluation of metal contamination and phytoremediation potential of aquatic macrophytes of East Kolkata Wetlands, India. Environ Health Toxicol 31:7.

Lone, M.A., He, Z. and Stoffella, P.J. 2008. Phytoremediation of heavy metal polluted soils and water: Progresses and perspectives. Journal Zhejiang University Science, B19: 210-220.

Lu, Q., He, Z.L., Graetz, D.A., Stoffela, P.J. and Yang, X. 2011. Uptake and distribution of metals by water lettuce (Pistia stratiotes L.) Environ. Sc. Poll. Res., 18: 978-986.

Meitei, M.D. and Prasad, M.N.V. 2016. Bioaccumulation of nutrients and metals in sediment, water,and phoomdi from Loktak lake (Ramsar site), northeast India: phytoremediation options and risk assessment. Environ. Monitoring Assess. 188: 329.

Miretzky, P., Saralegui, A. and Cirelli, A.F. 2010. Quantitative assessment of worldwide contamination of air, water and soil by trace elements. Nature, 279: 409-411.

Misra, R. 1968. Ecology Work Book, Oxford Publishing Company, Calcutta, pp. 242

Mueller-Dombois, D. and Ellenberg, H. 1974. Aims and Methods of Vegetation Ecology. John Willey and Sons, USA., pp. 547.

Prasad, S.N., Ramachandra, T.V., Ahalya, N., Sengupta T., Kumar,A., Tiwari A. K., Vijayan V. S. and Vijayan, L. 2002. Conservation of wetlands of India-a review. Tropical Ecology, 43: 173-186.

Pratas, J., Favas, P.J.C., Paulo, C., Rodrigues, N. and Prasad, M.N.V. 2012. Uranium accumulation by aquatic plants from uranium-contaminated water in Central Portugal. Inter. J. Phytorem., 14: 221-234.

Rai, P.K. 2008. Mercury pollution from chlor-alkali industry in a tropical lake and its bio-magnification in aquatic biota: Link between chemical pollution, biomarkers and human health concern. Human Ecol. Risk Assess., 14: 1318-1329.

Rai, P.K. 2010. Seasonal Monitoring of heavy metals and physico-chemical characteristics in a lentic ecosystem of sub-tropical industrial region, India. Environ. Monit. Assess., 165: 407-433.

Rai, P.K. 2018a. Heavy metals phyto-technologies from a Ramsar wetland plants: Green approach. Chemistry and Ecology, 34(8): 786-796

Rai, P.K. 2019. Heavy metals/metalloids remediation from wastewater using free floating macrophytes of a natural wetland. Environ. Technol. \&
Innovation, 15: 100393

Rai, P.K., Kumar, V., Lee, S.S., Naddem, R., Ok, Y.S., Kim, K.H. and Tsang, D.S.W. 2018. Nanoparticle-Plant interaction: implications in energy, environment, and agriculture. Environ. Int., 119: 1-19.

Rai, P.K., Lee, J., Kailasa, S.K., Kwon, E.K., Tsang, Y.F., Ok, Y.S. and Kim, K.H. 2018a. A critical review of ferrate (VI)-based remediation of soil and groundwater. Environ. Res., 160: 420-448.

Rai, P.K., Lee, S.S., Zhang, M., Tsang, Y.F. and Kim, K.H. 2019. Heavy metals in food crops: Health risks, fate, mechanisms and management. Environ. Int., 125: 365-385.

Rai, P.K. 2018. Phytoremediation of emerging contaminants in wetlands. CRC Press, Taylor \& Francis, Boca Raton, USA, pp. 248.

Rai, P.K. and Kim, K.H. 2020. Invasive alien plants and environmental remediation: A new paradigm in sustainable restoration ecology. Restoration Ecology 28(1), 3-7.

Rai, P.K., Kim, K.H., Lee, S.S. and Lee, J.H. 2020. Molecular mechanisms in phytoremediation of environmental contaminants and prospects of engineered transgenic plants/microbes. Sci. Total Enviro. 705: 135858.

Rai, P.K. and Singh, J.S. 2020. Invasive alien plant species: their impact on environment, ecosystem services and human health. Ecol. Indicators, 111: 106020 .

Ramsar secretariat 2013. The list of wetlands of international importance. The secretariat of the convention on wetlands, Gland, Switzerland.

Sharma, S. and Sujatha, D. 2016. Characterization of the water chemistry, sediment ${ }^{13} \mathrm{C}$ and ${ }^{18} \mathrm{O}$ compositions of Kolleru Lake-A Ramsar wetland in Andhra Pradesh, India. Environ. Monit. Assess., 188: 409.

Singh, M.M. and Rai, P.K. 2016. Microcosm investigation of Fe (iron) removal using macrophytes of Ramsar Lake: A phytoremediation approach. Inter. J. Phytoremed., 18(12): 1231-1236.

Sood, A., Uniyal, P.P., Prasanna, R. and Ahluwalia, A.S. 2012. Phytoremediation potential of aquatic macrophyte, Azolla. Ambio, 41: 122-137.

Tombi, H. and Shyamananda, R.K. 1994. Loktak. World Wide Fund, New Delhi.

Valderrama, A., Tapia, J., Penailillo, P. and Carvajal, D.E. 2013. Water phytoremediation of cadmium and copper using Azolla filiculoides Lam. In a hydroponic system. Water Environ Journal, 27: 293-300.

Xin, K., Huang, X., Hu, J.L., Li, C., Yang, X.B. and Arndt, S.K. 2014. Land use change impacts on heavy metal sedimentation in mangrove wetlands-a case study in Dongzhai Harbor of Hainan, China. Wetlands, 34: 1-8.

Xue, P., Li, G., Liu, W. and Yan, C. 2010. Copper uptake and translocation in a submerged aquatic plants Hydrilla verticillata (L.f) Royle. Chemosphere, 81: 1098-1103.

Zhang, G., Bai, J., Zhao, Q., Lu, Q., Jia, J. and Wen, X. 2016 Heavy metals in wetland soils along a wetland-forming chronosequence in the Yellow River Delta of China: Levels, sources and toxic risks. Ecol. Indicators, 69: 331-339. 